\title{
Indirect Spectrophotometric Determination of Nitrazepam by Charge Transfer Complex Formation Reaction Using $p$-Bromanil as $\pi$-Acceptor
}

\author{
Subhi M. Al-Mtaiwti \\ Department of Chemistry, College of Education of Pure Science, Mosul University, Mosul, Iraq \\ Email: drsubhi74@uomosul.edu.iq
}

(Received January 22, 2013; Accepted March 06, 2013; Available online March 01, 2020)

DOI: 10.33899/edusj.2020.164373, (C) 2020, College of Education for Pure Science, University of Mosul.

This is an open access article under the CC BY 4.0 license (http://creativecommons.org/licenses/by/4.0/).

\begin{abstract}
:
A sensitive spectrophotometric method for the determination of nitrazepam in pure as well as in dosage form is described. The method is based on the reaction of reduced nitrazepam (RNZ) with p-bromanil in the presence of borate buffer solution of $\mathrm{pH} 9$ to form a pink color charge transfer(CT) complex of maximum absorption at $340 \mathrm{~nm}$. Under the optimized reaction conditions, Beer's law correlating the absorbance with nitrazepam concentration was obeyed in the range of $0.8-9.6 \mu \mathrm{g} \mathrm{ml}^{-1}$. The molar absorptivity was $1.977 \times 10^{4} \mathrm{~L} \mathrm{~mol}^{-1} \mathrm{~cm}^{-1}$. The limits of detection was $0.093 \mu \mathrm{g} \mathrm{ml}^{-1}$. The accuracy and precision of the method were satisfactory; the average recovery was $102 \%$ and values of relative standard deviations better than $1.5 \%$. The stoichiometry of the reaction was studied, and the reaction mechanism was postulated. The proposed CT complex formation method was successfully applied to the determination of nitrazepam in its pharmaceutical tablet with good accuracy and precision. The results obtained by the proposed method are compared with those obtained by the official method.
\end{abstract}

Keywords: Spectrophotometry; Charge transfer complex; nitrazepam; p-bromanil.

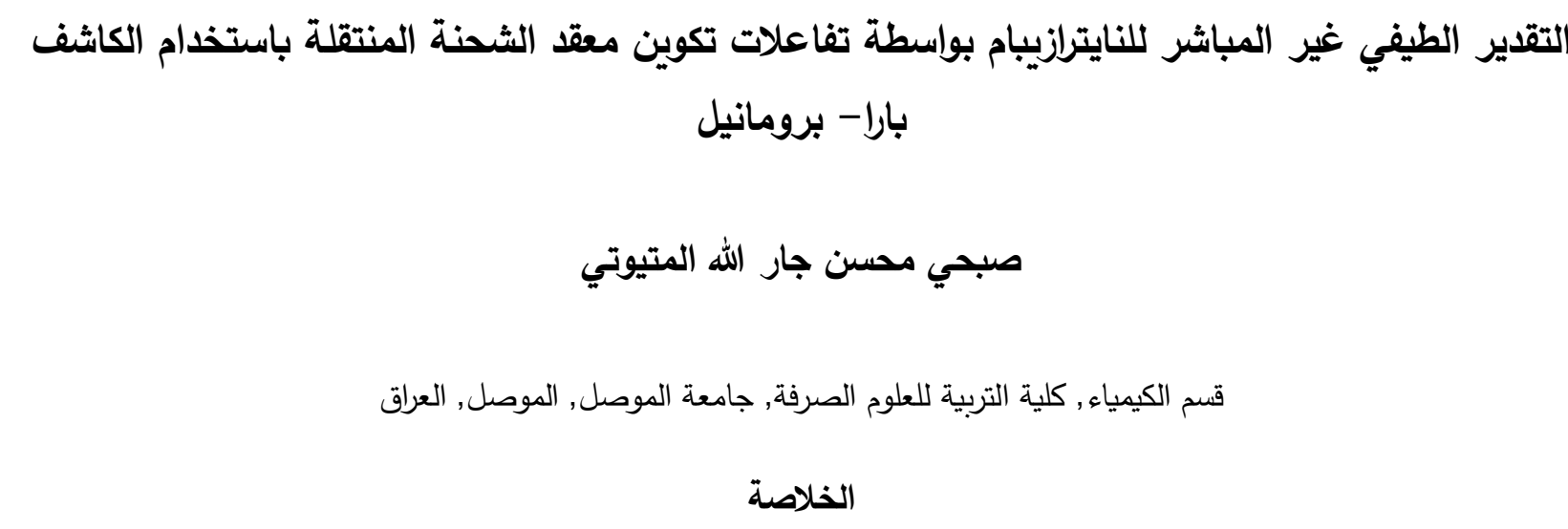

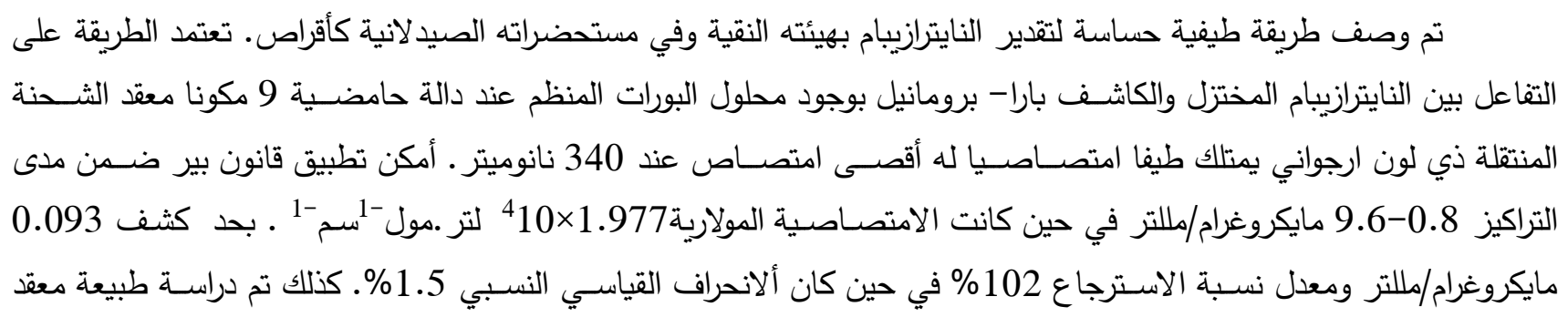




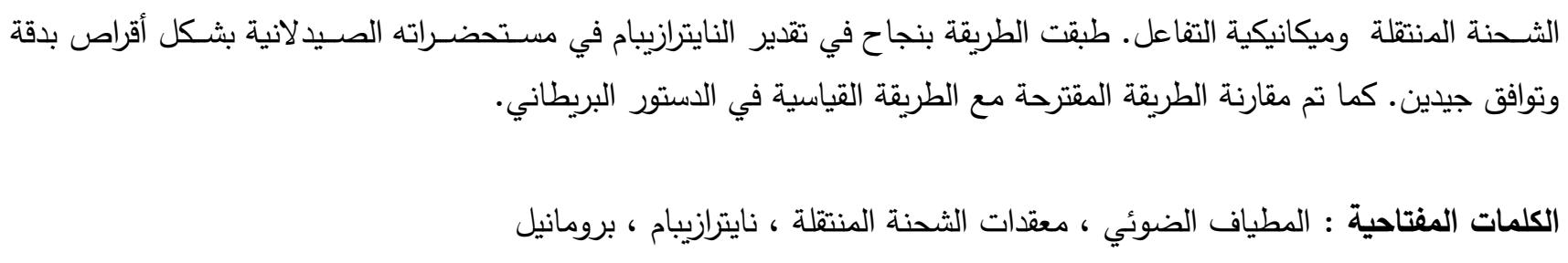

\section{Introduction}

Nitrazepam, (NZ) chemically known as 1,3-dihydro-1-nitro-2-oxo-5-phenyl 2H-1,4benzodiazepine-2-one (Figure 1), is a hypnotic agent that belongs to the benzodiazepine class, Nitrazepam used in the treatment of insomnia which has sedative and motor impairing properties [1], as well as anxiolytic, amnestic, anticonvulsant and skeletal muscle relaxant properties, and it has been used in the treatment of stress related disorders [2] .

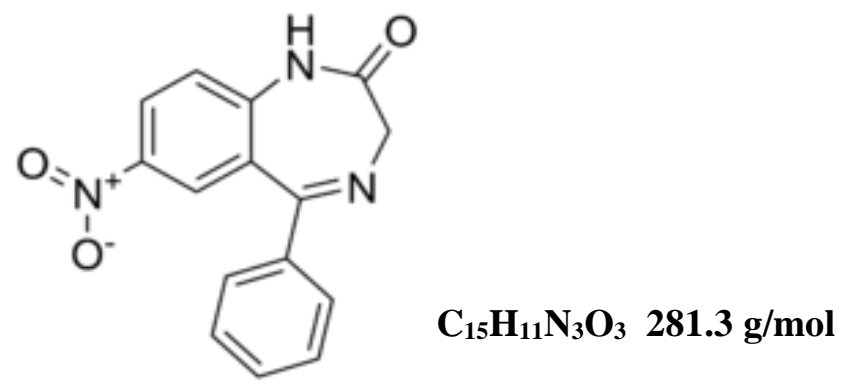

Figure 1: Structure of nitrazepam

Official spectrophotometric method for its determination in tablet has been reported in British Pharmacopoeia[1]. Various other spectrophotometric methods have been reported based on reduction of nitrazepam by using $\mathrm{Zn} / \mathrm{HCl}$ and measuring the difference in their absorbance before and after reduction [3], coupling of the diazotized NZ with different reagents such as resorcinol [4] or N-(1naphthyl) ethylene diamine) dihydrochloride [5], oxidation by ferric sulfate and coupling with pyrocatechol [6] and use of metol as $\pi$ acceptor forming charge transfer complex with reduced NZ as n-donor [7]. Methods based on other techniques such as HPLC[8,9], polarography [10], complexometry [11], GC with electron capture [12] have been used for the determination of NZ in biological fluids and pharmaceutical samples.

The present investigation method is development of sensitive spectrophotometric procedure for the estimation of $\mathrm{NZ}$ in both pure and in pharmaceutical preparation as tablet based on the reduction of $\mathrm{NZ}$ by $\mathrm{Zn}$ powder / $\mathrm{HCl}$ and interaction as $n$-donor with $p$-bromanil as $\pi$-acceptor in aqueous solution to form charge transfer complex.

\section{Experimental}

\section{Apparatus}

Shimadzu UV-180 PC UV-Visible double-beam spectrophotometer equipped with a $1.0-\mathrm{cm}$ path length quartz cell, Philips PW (9421) pH-meter with a combined glass electrode was used for $\mathrm{pH}$ measurements. Heating the solutions was carried out on water bath of frost instruments, LTD. All calculations in the computing process were performed in Microsoft Excel Windows 


\section{Chemicals}

All reagents were of analytical-reagent grade which were provided by BDH and Fluka companies.

Working standard solution of RNZ: Accurately $50 \mathrm{mg}$ of NZ was weighed into a separate $100 \mathrm{ml}$ beaker and dissolved NZ in $20 \mathrm{ml}$ absolute ethanol with heating. To this solution $5 \mathrm{ml}$ of conc. hydrochloric acid and $1 \mathrm{~g}$ of zinc dust were added and shaken thoroughly for $15 \mathrm{~min}$ and then diluted up to the mark with water in a $100 \mathrm{ml}$ standard flasks $\left(500 \mu \mathrm{g} \mathrm{ml}^{-1}\right)$, and filter through Whatmann no.41 filter paper, and then $20 \mathrm{ml}$ from this solution was neutralize with $20 \%$ sodium carbonate solution to $\mathrm{pH} 6$ and filtered using sintered glass crucible No.2 and diluted with water in $100 \mathrm{ml}$ calibrated flask to obtain $100 \mu \mathrm{g} \mathrm{ml}^{-1}$.

p-Bromanil $\left(\mathbf{1} \times \mathbf{1 0}^{-3} \boldsymbol{M}\right)$ : Prepared by dissolving $0.0424 \mathrm{~g}$ of

p-bromanil in $100 \mathrm{ml}$ absolute ethanol.

Borate buffer solution (0.05M pH 9): Prepared by dissolving $1.904 \mathrm{~g}$ of disodium tetraborate in 100 $\mathrm{ml}$ distilled water and the $\mathrm{pH}$ was adjusted by $\mathrm{pH}$ measurement.

Sodium hydroxide $\left(\mathbf{1 \times 1 0 ^ { - 2 }} \mathbf{M}\right)$ was prepared by dissolving $0.1 \mathrm{~g}$ in $250 \mathrm{ml}$ of distilled water.

\section{Recommended procedure}

An aliquot of a standard solution containing 0.8-9.6 $\mu \mathrm{g} \mathrm{ml}^{-1}$ of $\mathrm{RNZ}$ was transferred into a series of $25 \mathrm{ml}$ calibrated flasks. A volume of $1 \mathrm{ml}$ borate buffer solution was added to each flask followed by addition of $2.5 \mathrm{ml}$ p-bromanil solution. The contents of the reaction mixture were diluted to the mark with distilled water and kept in a water bath adjusted at $35^{\circ} \mathrm{C}$ for $40 \mathrm{~min}$,. The absorbance of the colored complex was measured at $340 \mathrm{~nm}$ against the reagent blank prepared in similar manner.

\section{Procedure for NZ assay in tablets}

Ten tablets (each tablet containing 5mg) were weighted, pulverized. A quantity of the powder equivalent to $25 \mathrm{mg}$ of $\mathrm{NZ}$ was weighed accurately and dissolved in $10 \mathrm{ml}$ absolute ethanol into a separate $50 \mathrm{ml}$ calibrated flask. Then, $5 \mathrm{ml}$ of conc. hydrochloric acid and $1 \mathrm{~g}$ of zinc dust were added and shaken thoroughly for about $30 \mathrm{~min}$. The volume was diluted to the mark with distilled water, mixed well and filtered using a Whatman No.41 filter paper and $20 \mathrm{ml}$ from this solution was neutralized with $20 \%$ sodium carbonate solution to $\mathrm{pH} 6$ and filtered using sintered glass crucible No.2 and diluted with water in $100 \mathrm{ml}$ calibrated flask to obtain $100 \mu \mathrm{g} \mathrm{ml}^{-1}$.

\section{Results and discussion Spectral characteristics}

The proposed method involves the reduction of $\mathrm{NZ}$ and reaction with $p$-bromanil reagent in the presence of borate buffer solution of $\mathrm{pH} 9$ to form a pink colored charge transfer complex having maximum absorption at 340nm. This wavelength was used for all subsequent measurements. The absorption spectra of the reaction product are shown in Figure 2. The corresponding reagent blank have low absorbance at this wavelength. Where as the reagent blank has a maximum absorption at 317 $\mathrm{nm}$ versus distilled water. 


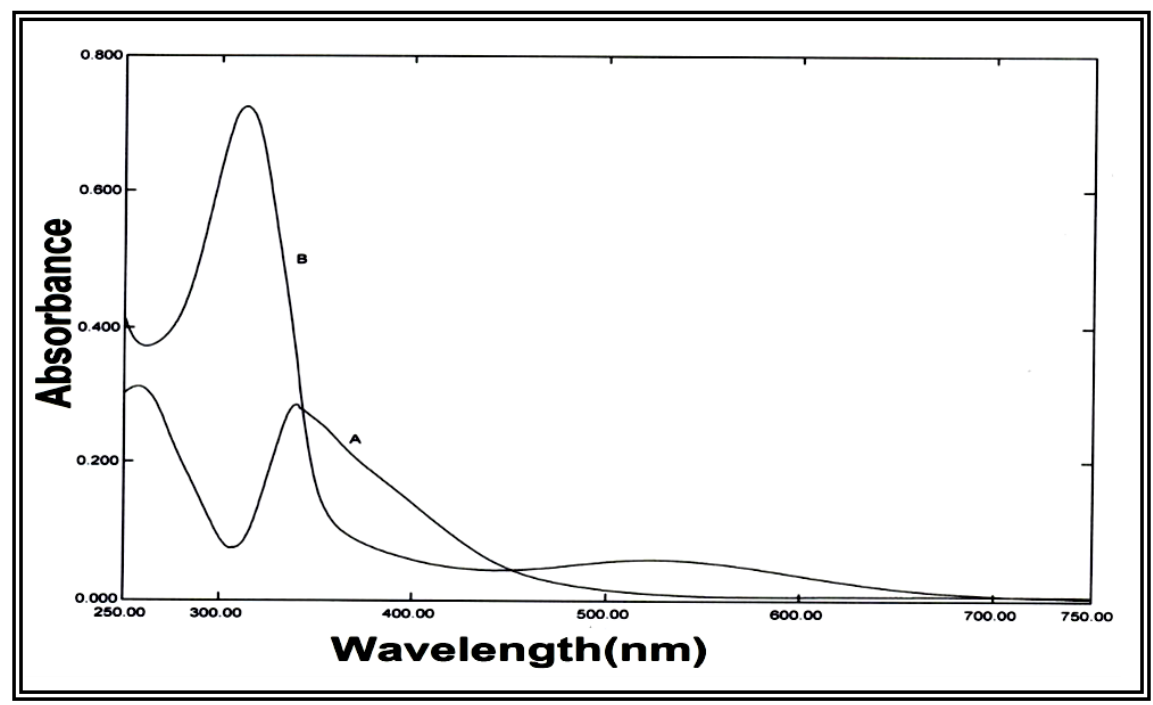

Figure 2: Absorption spectra of (A) RNZ (4 $\left.\mu \mathrm{g} \mathrm{ml}^{-1}\right)$ complex with p-bromanil reagent $\left(1 \times 10^{-2} \mathrm{M}\right)$ against reagent blank and $(B)$ reagent blank against distilled water under the optimum conditions

The optimum conditions for the color development of the p-bromanil-RNZ CT complex were established by for different parameters. The following experiments were conducted for this purpose and conditions so obtained were incorporated in general procedure.

\section{Effect of solvents}

Different solvents such as water, methanol, ethanol, acetonitrile, and acetone as medium for the reaction have been examined in order to achieve maximum sensitivity and complex stability. It was found that on using water as solvent for the drug, ethanol as solvent for $p$-bromanil and dilution with water gave maximum color intensity. So; this system of solvents have been recommended in this method.

\section{Effect of pH, buffer solutions and bases}

The effect of $\mathrm{pH}$ was studied in the range 6-10 using $\mathrm{NaOH}$ solution. The maximum absorbance value was obtained with $\mathrm{pH} 9$ in the presence of $0.5 \mathrm{ml}$ of $0.01 \mathrm{M} \mathrm{NaOH}$ (Figure 3). Therefore different buffers of $\mathrm{pH} 9$ were prepared by using phosphate, borate and carbonate buffers to investigate the sensitivity of the complex. As shown in Figure 4, it was found that borate buffer gave high absorbance value. So its selected in the subsequent experiments. However; the effect of borate buffer amount was studied and it was found that $1.0 \mathrm{ml}$ gave maximum color intensity and chosen as the optimum amount, and beyond this amount, the absorbance would be decreased, (Figure 5). 


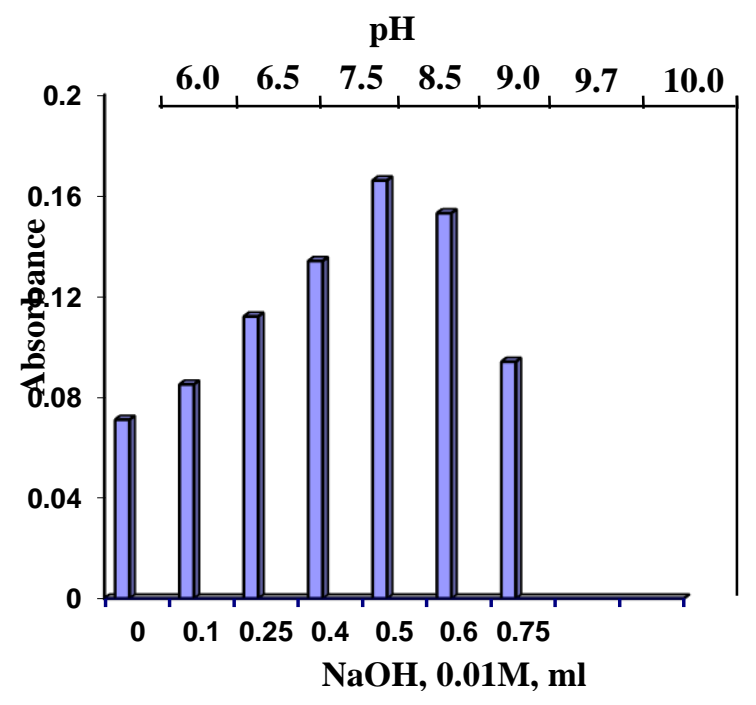

Figure 3: Effect of $\mathrm{pH}$ on the absorption of $4 \mu \mathrm{gmI}^{-1} \mathrm{RNZ}$

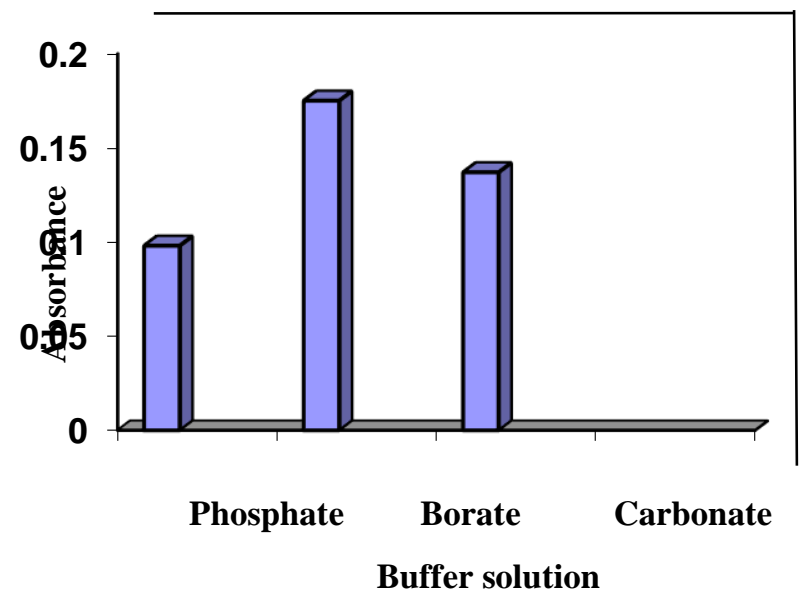

Figure 4: Effect of buffer solution on the absorption of $4 \mu \mathrm{gml}^{-1} \mathrm{RNZ}$

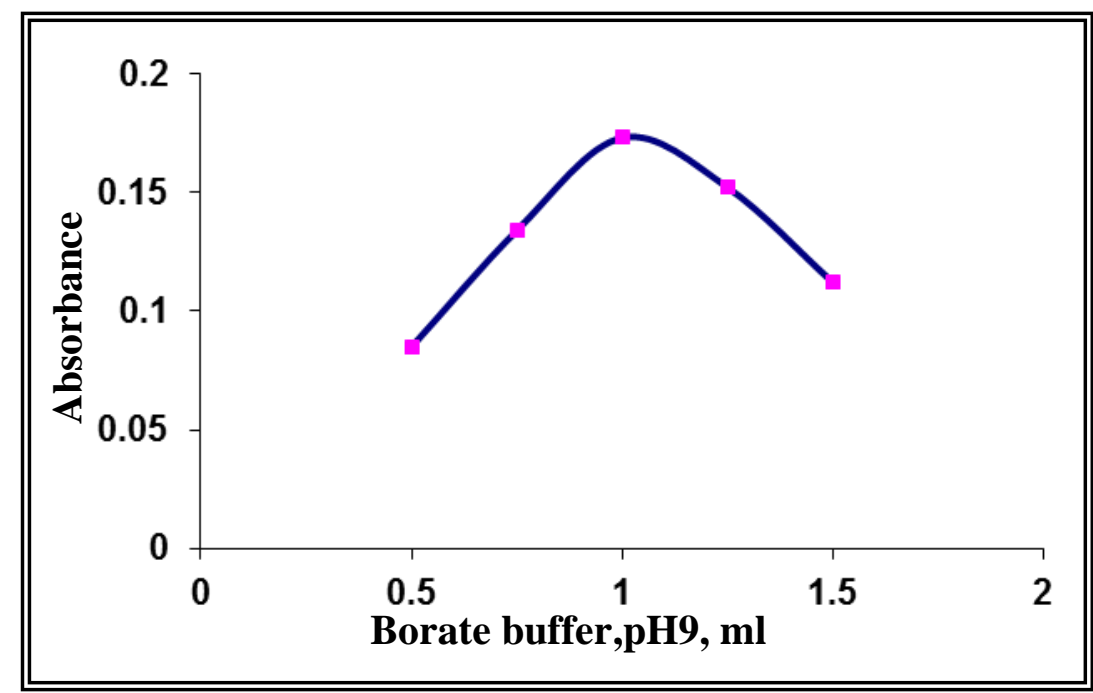

Figure 5: Effect of borate buffer solution amount on the absorption of $4 \mu \mathrm{gml}^{-1} \mathrm{RNZ}$

\section{Effect of $p$-bromanil $1 \times 10^{-2}$ concentration}

The effect of changing the $p$-bromanil concentration on the absorbance of solution containing a fixed amount of the drug was studied. As shown in Figure 6, it was found that the absorbance increases with increasing $p$-bromanil concentration and reached maximum on using $2.5 \mathrm{ml}$ which is selected in the subsequent work. 


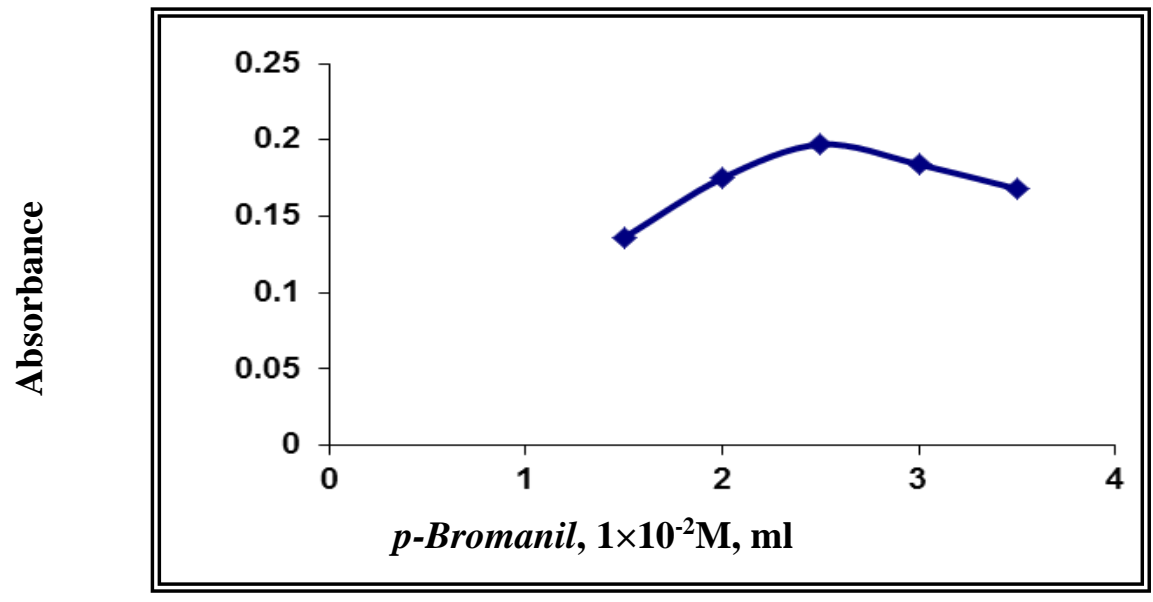

Figure 6: Effect of $p$-bromanil reagent concentration on the absorption of $4 \mu \mathrm{gml}^{-1} \mathrm{RNZ}$

\section{Effect of temperature and reaction time}

The reaction time was determined by following the color development at room temperature $\left(20^{\circ} \mathrm{C}\right)$ and in thermostatically controlled water-bath at different temperatures up to $45^{\circ} \mathrm{C}$. The absorbance was measured at 5 and 10 minutes intervals against reagent blank treated similarly. It was found that the color complex showed maximum absorbance after $40 \mathrm{~min}$ at $35^{\circ} \mathrm{C}$ and was stable for a further $60 \mathrm{~min}$, (Figure 7). Above $35^{\circ} \mathrm{C}$, the absorbance decreases, indicating dissociation. Hence, $40 \mathrm{~min}$ at $35^{\circ} \mathrm{C}$ are recommended for the proposed method.

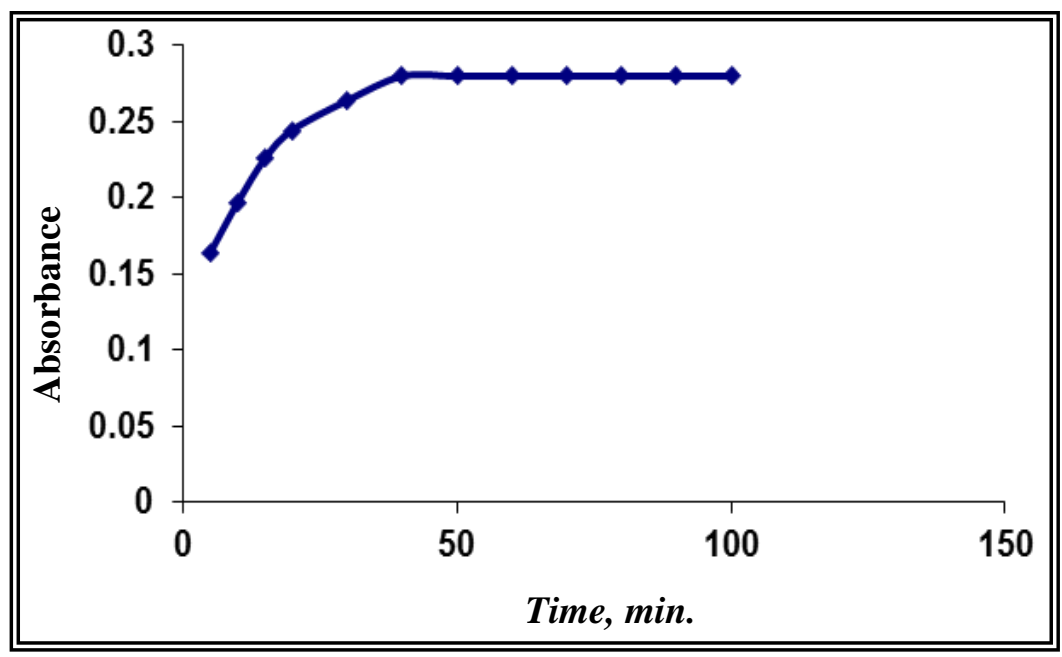

Figure 7: Effect of temperature on the absorbance of $4 \mu \mathrm{gml}^{-1}$ RNZ with $p$-bromanil at $35^{\circ} \mathrm{C}$

\section{Effect of order of addition}

To obtain optimum results the order of addition of reagents should be followed as given under the general procedure, otherwise a loss in color intensity was observed.

\section{Quantification}

In order to investigate the range in which the colored product adhere to Beer's law, the absorbance of the complex was measured at 340nm value after developing the color by following the suggested procedure for a series of solutions containing increasing amounts of RNZ (Figure8). The Beer's law limits and molar absorptivity values were evaluated and given in Table 1, indication that 
the method is sensitive. The linearity was represented by the regression equation and the corresponding correlation coefficient for drug determined by the proposed method represents excellent linearity. The relative standard deviation (RSD) and accuracy (average recovery \%) for the analysis of six replicates of each three different concentrations for RNZ indicated that the method is precise and accurate. Limit of detection (LOD) is in the accepted range below the lower limit of Beer's law range.

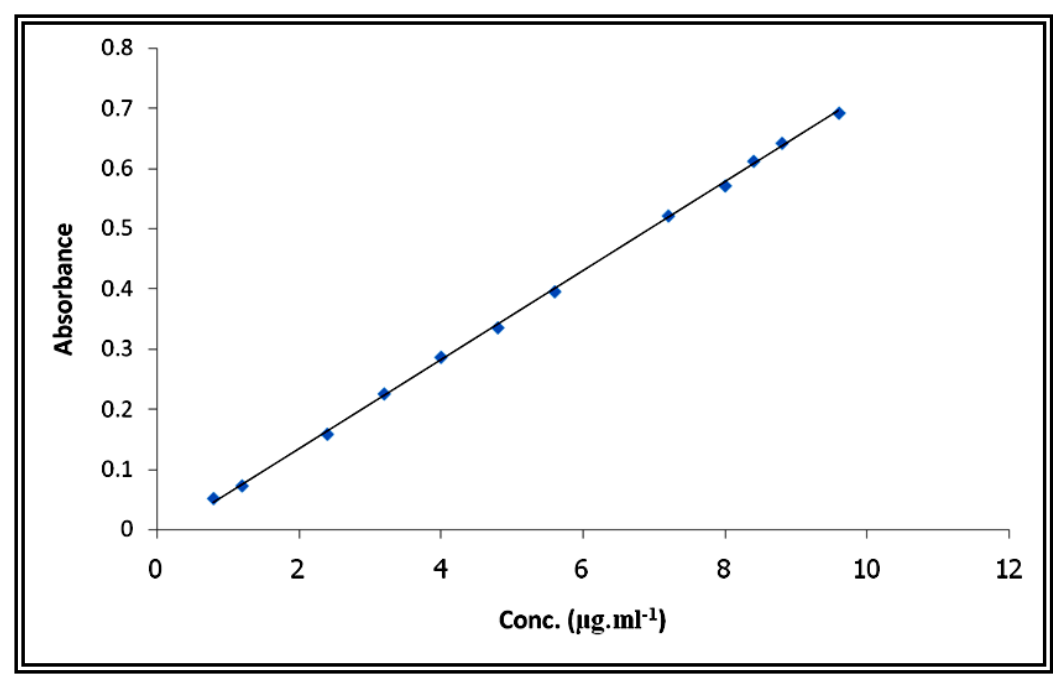

Figure8: Calibration graph for determination of nitrazepam

Table 1: Summary of optical characteristics and statistical data for the proposed method

\begin{tabular}{ll}
\hline Parameter values of method & \\
\hline Beer's law limits $\left(\mu \mathrm{ml}^{-1}\right)$ & $0.8-9.6$ \\
Molar absorptivity $\left(\mathrm{l} \cdot \mathrm{mol}^{-1} \cdot \mathrm{cm}^{-1}\right)$ & $1.977 \times 10^{4}$ \\
LOD $\left(\mu \mathrm{g} \cdot \mathrm{ml}^{-1}\right)$ & 0.093 \\
LOQ $\left(\mu \mathrm{g} \cdot \mathrm{ml}^{-1}\right)$ & 0.309 \\
Average recovery $(\%)^{\star \star}$ & 102 \\
Correlation coefficient & 0.9995 \\
Regression equation $(Y)^{*}$ & \\
Slope, $a$ & 0.073 \\
Intercept, $b$ & -0.013 \\
RSD** & $\leq 1.5$ \\
\hline
\end{tabular}

${ }^{\star} Y=a X+b$, where $X$ is the concentration of $\mathrm{NZ}$ in $\mu \mathrm{g} \mathrm{ml}{ }^{-1}$.

** Average of six determinations.

\section{Interference}

The extent of interference by some excipients usually present in pharmaceutical preparations were studied by measuring the absorbance of solutions containing $4 \mu \mathrm{gml}^{-1}$ of RNZ and various amounts of diverse species in a final volume of $25 \mathrm{ml}$. It was found that the studied excipients did not interfere seriously (Table 2). Slight positive interference was observed in the presence of large excess of excipients. However; an error of $5.0 \%$ in the readings was considered tolerable. The results are given in table 2 . 
Table 2: Effect of excipients for assay of the studied drug .

\begin{tabular}{|c|c|c|c|c|c|}
\hline \multirow{2}{*}{$\begin{array}{c}\text { Foreign } \\
\text { Compound }\end{array}$} & \multicolumn{5}{|c|}{ Recovery of $4 \mu \mathrm{ml}^{-1}$ of $\mathrm{NZ}$ per $\mu \mathrm{g} / \mathrm{ml}$ Foreign } \\
& \multicolumn{5}{|c|}{ added } \\
\cline { 2 - 6 } & 20 & 60 & 100 & 140 & 200 \\
\hline Glucose & 99.43 & 98.56 & 101.23 & 100.85 & 103.35 \\
\hline Lactose & 99.46 & 99.22 & 100.57 & 99.84 & 101.35 \\
\hline Arabic Gum & 100.25 & 100.78 & 101.35 & 101.28 & 102.65 \\
\hline Sodium chloride & 99.85 & 100.25 & 100.36 & 101.25 & 101.68 \\
\hline Starch & 101.55 & 101.89 & 99.35 & 100.85 & 102.25 \\
\hline
\end{tabular}

\section{Stoichiometry and Stability constant}

The molar ratio of the complex formed between the RNZ and p-bromanil reagent was investigated by applying the continuous variation (Job's) and mole ratio methods[13]. The results indicated that the complex was formed in the ratio of $1: 1$ for RNZ to the reagent (Figures 9). This finding supports that the $n-\pi$ CT complex is formed through the amino group which produced from the reduction of the nitrazepam drug.
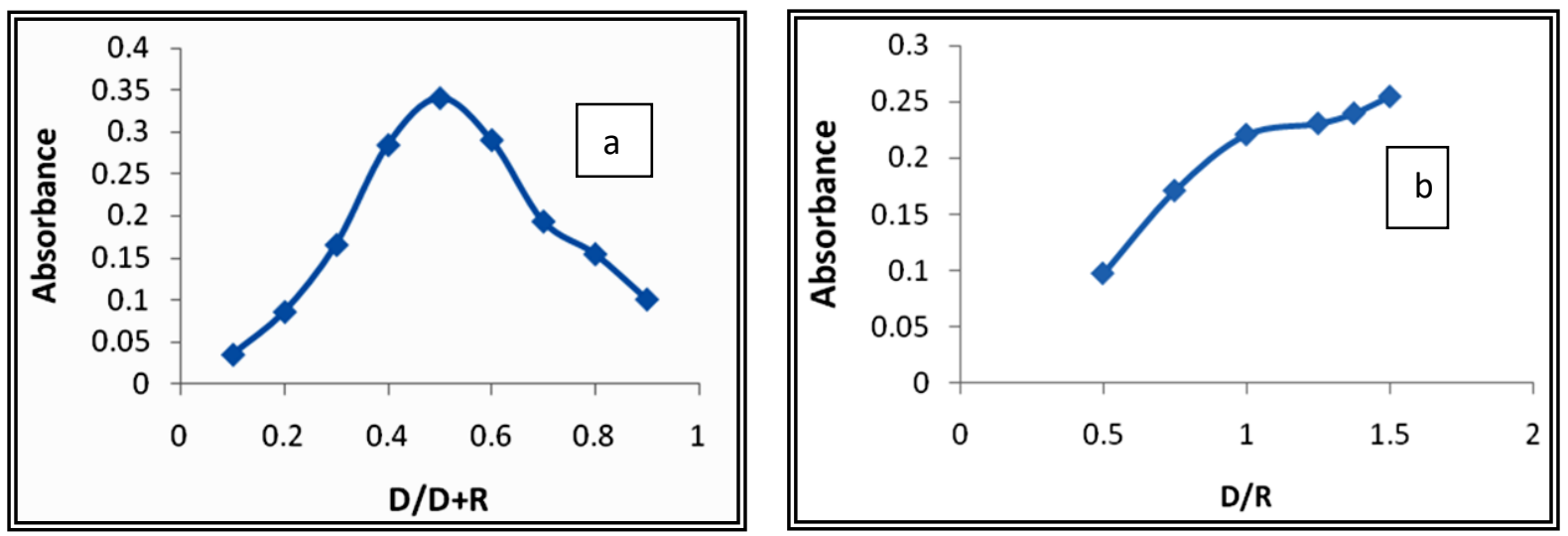

Figure 9: Continuous variation (a) and mole ratio (b) plots for complex of $\operatorname{RNZ}\left(3.98 \times 10^{-4} \mathrm{M}\right)$ and $p$-bromanil $\left(3.98 \times 10^{-4} \mathrm{M}\right)$ under the optimu conditions.

The apparent stability constant was estimated by comparing the absorbance of a solution containing stoichiometric amounts of the drug and p-bromanil (As) to one containing an excessive amount of $\mathrm{p}$ bromanil reagent (Am). The average conditional stability constant of the complex was calculated, according to the $1: 1$ ratio, by the following equation:

$$
\begin{gathered}
\mathrm{Kc}=(1-\alpha) / \alpha^{2} \mathrm{C} \\
\alpha=(\mathrm{Am}-\mathrm{As}) / \mathrm{Am}
\end{gathered}
$$

where $\mathrm{Kc}$ is the stability constant $\left(1 . \mathrm{mol}^{-1}\right), \alpha$ the dissociation degree and $\mathrm{C}$ the concentration of the product which is equal to the concentration of drug. However the average of stability constant for three different concentration was found $3.3 \times 10^{3} 1 . \mathrm{mol}^{-1}$ indicating high stability. 


\section{Reaction mechanism}

The nature of the reaction between RNZ as n-donor with p-bromanil as $\pi$-acceptor in aqueous solution is not clearly understood. However, in the present work it was observed that the complex is formed in aqueous medium in the ratio 1:1 after addition of RNZ, which including primary amino group, to $p$-bromanil reagent at $\mathrm{pH} 9$ and new absorption spectrum appeared at $340 \mathrm{~nm}$, which is not shown by either of the components present in solution. Also, it was found that $p$-bromanil reagent has an absorption spectrum at $\lambda_{\max }$ at $317 \mathrm{~nm}$ in the presence of $\mathrm{pH} 9$ which may be attributed to the formation of tribromohydroxy-p-benzoquinone [14] which is considered as a real complexing agent. However; complete electron transfer from the donor to the acceptor moiety took place with the formation of intensely colored radical ion with high molar absorptivity. On this basis, a suggested chemical reaction has been proposed in Illustration 1.
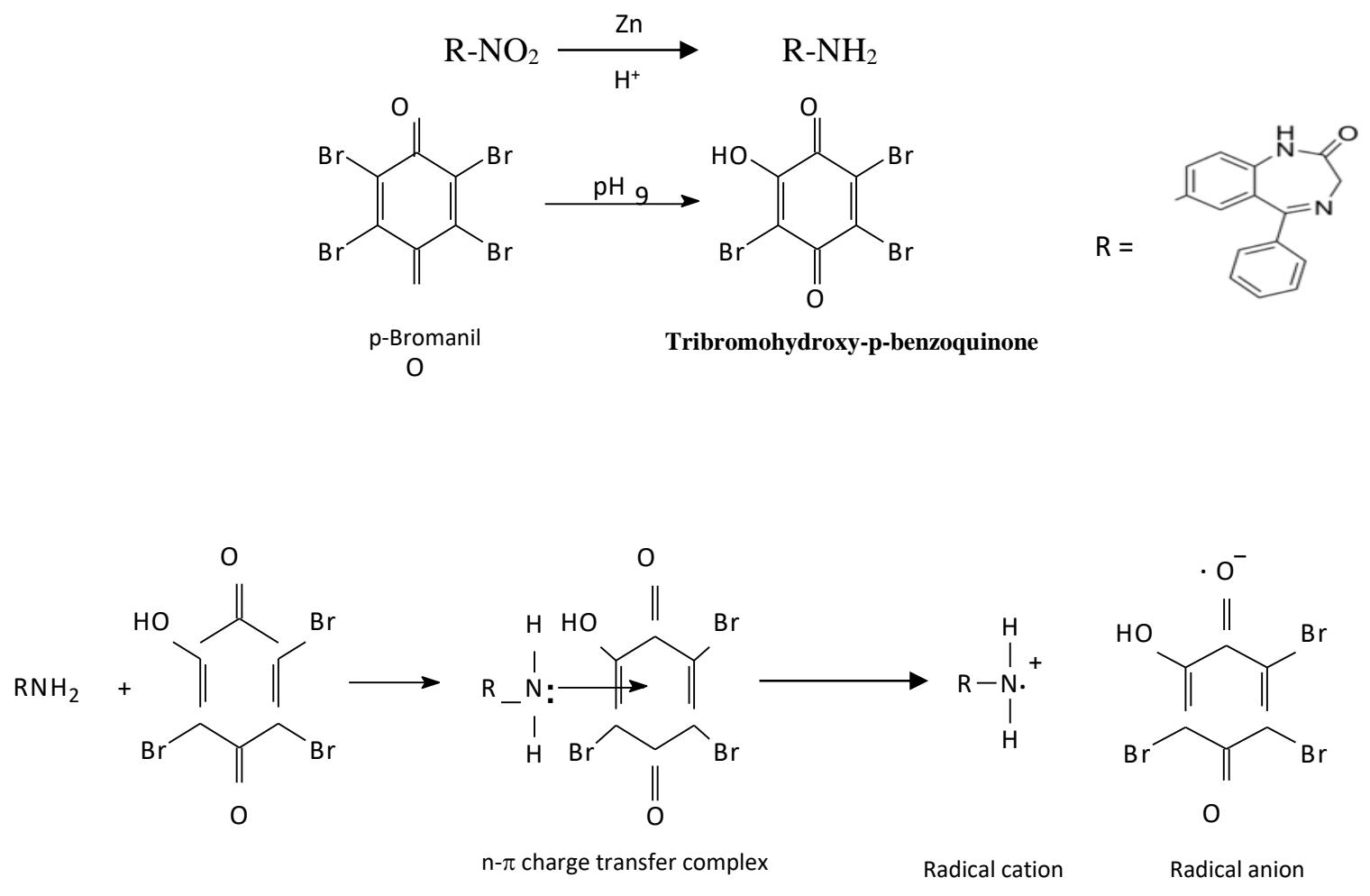

Illustration1:. Probable mechanism for RNZ-p-bromanil product formed. 


\section{Analytical application}

The proposed method was successfully applied to determine nitrazepam in its pharmaceutical preparation as tablet. The obtained results were compared statistically by student's t-test and F-test with the official method [1] at 95\% confidence level with five degrees of freedom, as cited in Table 3. The results showed that the $\mathrm{t}$ - test and F-test were less than the tabulated value $(\mathrm{t}=2.57, \mathrm{~F}=5.05)$ [11], indicating that there was no significant difference between the proposed method and official method.

Table 3: Assay of nitrazepan in tablet using proposed method and comparison with the official method

\begin{tabular}{|c|c|c|c|c|c|c|c|}
\hline $\begin{array}{l}\text { Procedure } \\
\text { applied }\end{array}$ & $\begin{array}{c}\text { Pharmace } \\
\text { utical } \\
\text { preparatio } \\
n\end{array}$ & $\begin{array}{c}\text { Drug } \\
\text { amount } \\
\text { present } \\
\left(\mu \mathrm{g} \mathrm{ml}^{-1}\right)\end{array}$ & $\begin{array}{c}\text { Recovery }{ }^{a} \\
(\%)\end{array}$ & $\begin{array}{c}\text { Drug } \\
\text { conte } \\
\text { nt } \\
\text { found } \\
\text { (mg) }\end{array}$ & $\begin{array}{l}\text { Average } \\
\text { recovery } \\
(\mathrm{mg})\end{array}$ & $\begin{array}{l}\text { Certified } \\
\text { value } \\
\text { (mg) }\end{array}$ & $\mathrm{RSD}^{\mathrm{a}}$ \\
\hline $\begin{array}{l}\text { Proposed } \\
\text { method }\end{array}$ & $\begin{array}{c}\text { Mogadon }^{\mathrm{c}} \\
\text { Tablet }^{-}\end{array}$ & $\begin{array}{l}2 \\
4 \\
6\end{array}$ & $\begin{array}{c}100.2 \\
99 \\
101\end{array}$ & $\begin{array}{c}5.1 \\
4.95 \\
5.05\end{array}$ & $\begin{array}{c}5.03 \\
(1.47,2.94 \\
)^{b}\end{array}$ & $5 \mathrm{mg}$ & 1.24 \\
\hline $\begin{array}{c}\text { British } \\
\text { Pharmacopoe } \\
\text { ia }\end{array}$ & $\begin{array}{c}\text { Mogadon } \\
\text { Tablet }\end{array}$ & $5(\mathrm{mg})$ & $\begin{array}{c}99 \\
101 \\
98.4\end{array}$ & $\begin{array}{l}4.95 \\
5.05 \\
4.92 \\
\end{array}$ & 4.98 & $5 \mathrm{mg}$ & 1.38 \\
\hline
\end{tabular}

$\mathrm{a}=$ Average of three determinations.

$\mathrm{b}=$ Figures in parenthesis are the calculated values for $t$, and $F$ respectively.

$\mathrm{c}=$ Marketed by Roche Co. Switzerland

\section{Conclusion}

The proposed spectrophotometric method is sensitive (trace amounts can be determined), accurate (average recovery $102 \%$ ), precise $(\mathrm{RSD} \leq 1.5)$ and simple since it does not need neither organic medium nor solvent extraction step. The proposed method was applied successfully for the assay of the pharmaceutical preparation for the studied drug as tablet . 


\section{References}

1- British Pharmacopia on CD-ROM . General Medical Council , 3rd edn, London . (2005)

2- Michael J. N, " Medical Pharmacology at a Glance" , $4^{\text {th }}$ Ed ,Blackwell SCi , UK .,(2002)

3- EL-Brashy A., Aly F. A., Belal F. , Determination of 1,4-benzdiazepines in drug dosage forms by difference spectrophotometry , Mikrochim. Acta, 110,55-60. (1993)

4- Al-GhabshaT.S.,AzzouzA.S.,ObeedA. N., Spectrophotometric method for determination of nitrazepam by using resorcinol as coupling agents , J. Edu. Sci. ,21(1),147-163. (2008)

5- Al-Shaker Y. , Hassan I. Y. ,Spectrophotometric determination of nitrazepam by coupling of diazotized reduced nitrazepam with N-(1- naphthyl)ethylenediaminedihydrochloride ,Raf. J. Sci. ,22(4),39-50. (2011)

6- Raghad S., Al-Abachi M. Q. , , Spectrophotometric determination of nitrazepam in pharmaceutical tablets by oxidative coupling reaction with pyrocatechol, J. of Univ. of Anbar for pure science ,3,30-41. (2009)

7- Hosaker D. ,Shiramally M., Hemavathi N, Spectrophotometric determination of nitrazepam and nimodipine in pure and the tablet dosage forms, Asian J. of Biochem. And pharma Rese. ,1,7077. (2011)

8- Pistos C. ,James T. S., Direct injection HPLC method for the determination of selected benzodiazepines in plasma using a Hisep column, J. Phama. And Biomed Anal. ,33(5), 1135-42. (2003)

9- Gui-fu M.,HPLC determination of diazepam ,nitrazepam ,and clonazepam in human plasma , Chinese J. of Hospital pharmacy ,11. (2004)

10- Arvind K. M. ,Kamal D. G, Polarographic assay of nitrazepam formulations ,Analyst, 110,110509. (1985)

11- Gajewaks M. ,Cizewka M. , Wojcik E. ,Complexometric determination of nitrazepam ,oxazepam and temazepam with cadmium 2-methyl-5-nitrobemzensulphoate ,ActaPoloniaePharma,41(2), 213-219. (1984) 
12- Sane R. T. ,Ghorpade U. A. ,Dolas S. M. , Gas chromatographic determination of nitrazepam and diazepam from pharmaceutical preparations , Indian Drugs ,24(5), 260-263. (1987)

13- Divad H. , " Modern Analytical Chemistry", McGraw-Hill Higher Edu. ,USA. (2000)

14- Al-Mtwaiti S.M., Ph.D Thesis,University of Mosul,p38. (2004) ( in Arabic ). 